\title{
Analisis Faktor-Faktor yang Berpengaruh Terhadap Jumlah Kematian Ibu dan Jumlah Kematian Bayi di Provinsi Jawa Tengah dengan Bivariate Generalized Poisson Regression
}

\author{
Maudi Pramedia Putri dan Purhadi \\ Jurusan Statistika, Fakultas Matematika dan Ilmu Pengetahuan Alam, Institut Teknologi Sepuluh Nopember (ITS) \\ J1. Arief Rahman Hakim, Surabaya 60111 Indonesia \\ e-mail: purhadi@statistika.its.ac.id dan pramediaputry@gmail.com
}

\begin{abstract}
Abstrak-Jumlah kematian ibu dan jumlah kematian bayi di Provinsi Jawa Tengah hingga akhir tahun 2015 masih memiliki tugas yang berat dalam memenuhi target MDGs. Jumlah kematian bayi di Jawa Tengah termasuk dalam 6 peringkat tertinggi di Indonesia dan untuk jumlah kematian ibu di Jawa Tengah dalam kurun waktu lima tahun terakhir terus mengalami peningkatan dan telah mengalami penurunan pada tahun 2015 akan tetapi belum memenuhi target MDGs, untuk itu perlu adanya upaya dari pemerintah Provinsi Jawa Tengah untuk menekan jumlah kematian ibu dan jumlah kematian bayi sehingga perlu dilakukan penelitian untuk menganalisis faktorfaktor yang mempengaruhi jumlah kematian ibu dan jumlah kematian bayi dengan menggunakan Bivariate Generalized Poisson Regression. Pada model terbaik yang diseleksi menggunakan nilai AIC yang signifikan mempengaruhi jumlah kematian ibu dan jumlah kematian bayi adalah persentase persalinan oleh tenaga kesehatan, persentase ibu hamil mendapatkan tablet $\mathrm{Fe} 3$, persentase komplikasi kebidanan yang ditangani, persentase rumah tangga ber-PHBS dan persentase ibu hamil melaksanakan program $\mathrm{K} 4$.
\end{abstract}

Kata Kunci-AIC, Bivariate Generalized Poisson Regression, Jawa Tengah, Kematian Bayi, Kematian Ibu.

\section{PENDAHULUAN}

$\mathrm{P}$ ROVINSI Jawa Tengah merupakan salah satu dari beberapa provinsi di Pulau Jawa yang masih memiliki tugas yang berat dalam memenuhi target MDGs yang terkait dengan upaya penurunan jumlah kematian ibu dan jumlah kematian bayi hingga akhir tahun 2015. Jumlah kematian ibu dan jumlah kematian bayi merupakan salah satu indikator penting dalam menentukan tingkat kesehatan masyarakat dan kesejahteraan suatu bangsa. Provinsi Jawa Tengah termasuk dalam 6 besar daerah dengan AKI dan AKB tertinggi di Indonesia. Jumlah kematian ibu di Jawa Tengah dalam kurun waktu lima tahun terakhir terus mengalami peningkatan, tercatat pada 2010 sebanyak 611 kasus, pada 2011 meningkat menjadi 668 kasus, pada 2012 naik menjadi 675 kasus, pada 2013 sebanyak 668 dan pada 2014 tercatat sebanyak 711 kasus sedangkan pada tahun 2015 menurun menjadi 619 kasus dengan AKI 111,16 sehingga nilai ini belum memenuhi target dari MDG's. Jumlah kematian bayi tertinggi Provinsi Jawa Tengah pada tahun 2015 terdapat pada Kabupaten Grobogan dengan jumlah kematian bayi sebesar 384 bayi dan jumlah kematian ibu tertinggi di Provinsi Jawa Tengah terdapat pada Kabupaten Brebes yaitu sebanyak 52 kematian ibu.

Penelitian mengenai kematian bayi telah beberapa kali dilakukan [1]-[5], menerapkan Generalized Poisson Regression (GPR) untuk data yang mengalami overdispersi. Selain itu, penelitian tentang kematian ibu dan kematian bayi juga dilakukan dengan menggunakan pendekatan regresi poisson bivariat. GPR yang terjadi pelanggaran asumsi rata-rata dan ragam yang sama. Pelanggaran asumsi tersebut yaitu ragam lebih besar daripada rata-rata disebut overdispersi. Kebaikan model menunjukkan bahwa GPR lebih baik daripada regresi Poisson [4]. BGPR bisa digunakan tidak hanya pada data count bivariat dengan korelasi positif, nol atau negatif tetapi juga data count bivariat yang under/over dispersi dengan hubungan antara ragam dan rata-rata yang fleksibel [5].

Data yang memiliki kasus over atau under dispersi tidak sesuai apabila dimodelkan menggunakan regresi Poisson. Untuk itu pada kasus over maupun under dispersi dapat dilakukan analisis menggunakan model GPR, Negative Binomial Regression, Zero-Inflated Poisson Regression dan Zero-Inflated Negative Binomial Regression. Pada model ZeroInflated Poisson Regression dan Zero-Inflated Negative Binomial Regression digunakan pada data yang terjadi over maupun under dispersi dengan banyak nilai nol pada variabel respon [6]. Kematian ibu dan kematian bayi merupakan dua hal yang saling terkait erat karena status gizi dan kesehatan ibu erat kaitannya dengan kesehatan bayi di dalam kandungan. Variabel respon yang digunakan dalam penelitian ini yaitu jumlah kematian ibu dan jumlah kematian bayi di Provinsi Jawa Tengah pada Tahun 2015. Pada penelitian ini model yang digunakan adalah Bivariate Generalized Poisson Regression karena data tersebut tidak banyak mengandung nilai nol dan diduga terjadi over/under dispersi, variabel respon yang digunakan merupakan peristiwa yang mengikuti distribusi poisson karena jarang terjadi serta merupakan sepasang count data yang memiliki korelasi. Hasil dari penelitian ini diharapkan dapat memberikan informasi kepada pemerintah mengenai kematian ibu dan bayi untuk mempermudah melakukan perencanaan program preventif di Provinsi Jawa Tengah sebagai upaya penurunan jumlah kematian ibu dan bayi berdasarkan faktor-faktor yang berpengaruh di Provinsi Jawa Tengah. 


\section{TINJAUAN PUSTAKA}

\section{A. Generalized Poisson Regression}

Regresi Poisson mengasumsikan variabel respon menyebar Poisson, tidak ada multikolinieritas antar variabel prediktor dan memiliki ragam yang sama dengan rata-rata. Asumsi multikolinieritas dapat dilihat dari nilai korelasi antar variabel prediktor. Pada data overdispersi atau underdispersi regresi poisson tidak dapat digunakan karena pendugaan dalam regresi poisson menjadi tidak efisien. Oleh karena itu digunakan pendekatan model model yang lebih sesuai untuk mengatasi kondisi overdispersi atau underdispersi. Salah satu model yang sesuai untuk mengatasi overdispersi atau underdispersi adalah Generalized Poisson Regression. Sehingga selain $\mu$ dalam Genaralized Poisson terdapat juga $\alpha$ sebagai parameter dispersi. Pengujian overdispersi atau underdispersi dilakukan dengan menggunakan uji Lagrange Multiplier dengan mengguna-kan hipotesis sebagai berikut [7].

$H_{0}: \theta=0$

$H_{1}: \theta \neq 0$

Statistik uji yang digunakan adalah sebagai berikut.

$$
T_{L M}=\left(\sum_{i=1}^{n} \frac{1}{2} \mu_{i}^{-2} g^{2}\left(\mu_{i}\right)\right)^{-1 / 2} \sum_{i=1}^{n} \frac{1}{2} \mu_{i}^{-2} g^{2}\left(\mu_{i}\right)\left\{\left(y_{i}-\mu_{i}\right)^{2}-y_{i}\right\}
$$

dimana $\mathrm{g}\left(\mu_{i}\right)=\mu_{i}^{2}$

Tolak $\mathrm{H}_{0}$ apabila nilai $\left|\mathrm{T}_{\mathrm{LM}}\right|$ lebih besar dari $\mathrm{Z}_{\alpha}$. Apabila nilai $\mathrm{T}_{\mathrm{LM}}$ lebih besar dari $Z_{\alpha}$ maka terjadi kasus overdispersi sedangkan jika nilai $T_{L M}$ lebih kecil dari $Z_{\alpha}$ maka terjadi kasus underdispersi.

\section{B. Bivariate Generalized Poisson Regression}

Bivariate Poisson Regression merupakan suatu metode yang digunakan untuk memodelkan sepasang data count yang memiliki korelasi dengan beberapa variabel prediktor [8]. Model Bivariate Poisson Regression dapat dituliskan :

$$
\left(Y_{1 i}, Y_{2 i}\right) \sim P B\left(\mu_{1 i}, \mu_{2 i}, \mu_{0}\right)
$$

dimana,

$$
\begin{aligned}
& \mu_{j i}+\mu_{0}=e^{x_{i}^{T} \beta_{J}} ; j=1,2 \text { dan } i=1,2, \ldots, n \\
& \mathbf{x}_{\mathrm{i}}=\left[\begin{array}{lllll}
1 & \mathrm{x}_{1 \mathrm{i}} & \mathrm{x}_{2 \mathrm{i}} & \ldots & \mathrm{x}_{\mathrm{ki}}
\end{array}\right]^{\mathrm{T}} \\
& \boldsymbol{\beta}_{\mathrm{j}}=\left[\begin{array}{lllll}
\beta_{\mathrm{j} 0} & \beta_{\mathrm{j} 1} & \beta_{\mathrm{j} 2} & \ldots & \beta_{\mathrm{jk}}
\end{array}\right]^{\mathrm{T}}
\end{aligned}
$$

Jika $\left(Y_{1 i}, Y_{2 i}\right) \sim G P B\left(\mu_{1 i}, \mu_{2 i}, \alpha_{1}, \alpha_{2}\right)$ maka model dari Bivariate Generalized Poisson Regression adalah

$$
\begin{aligned}
\ln \left(\mu_{j i}\right) & =\mathbf{x}_{\mathbf{i}}^{\mathrm{T}} \boldsymbol{\beta}_{\mathbf{j}}=\beta_{j 0}+\beta_{j 1} x_{1 i}+\beta_{j 2} x_{2 i}+\ldots+\beta_{j k} x_{k i} \\
\mu_{j i} & =\exp \left(\mathbf{x}_{\mathbf{i}}^{\mathbf{T}} \boldsymbol{\beta}_{\mathbf{j}}\right)=\exp \left(\beta_{j 0}+\beta_{j 1} x_{1 i}+\beta_{j 2} x_{2 i}+\ldots+\beta_{j k} x_{k i}\right)
\end{aligned}
$$

dimana

$$
\begin{aligned}
& \mathbf{x}_{i}=\left[\begin{array}{lllll}
1 & x_{1 i} & x_{2 i} & \ldots & x_{k i}
\end{array}\right]^{T} \\
& \boldsymbol{\beta}_{j}=\left[\begin{array}{lllll}
\beta_{j 0} & \beta_{j 1} & \beta_{j 2} & \ldots & \beta_{j k}
\end{array}\right]^{T} j=1,2 \text { dan } i=1,2, \ldots, n
\end{aligned}
$$

\section{i.) Pendugaan Parameter Bivariate Generalized Poisson Regression}

Metode pendugaan parameter Bivariate Generalized Poisson Regression (BGPR) adalah Maximum Likelihood Estimation
(MLE) dengan fungsi likelihood dari Bivariate Generalized Poisson yaitu,

$L\left(\mu_{0}, \mu_{1 i}, \mu_{2 i}, \alpha_{1}, \alpha_{2}, \alpha_{0}\right)=$

$\prod_{i=1}^{n} \mu_{0} \mu_{1 i} \mu_{2 i} \exp \left\{-\left(\mu_{0}+\mu_{1 i}+\mu_{2 i}\right)-y_{1 i} \alpha_{1}-y_{2 i} \alpha_{2}\right\}^{\min \left(y_{i, j} y_{2 i}\right)} \frac{\left(\mu_{1 i}+\left(y_{1 i}-k\right) \alpha_{1}\right)^{y_{i j}-k-1}}{\left(y_{1 i}-k\right) !}$

$\frac{\left(\mu_{2 i}+\left(y_{2 i}-k\right) \alpha_{2}\right)^{y_{2 i}-k-1}}{\left(y_{2 i}-k\right) !} \times \frac{\left(\mu_{0}+k \alpha_{0}\right)^{k-1}}{k !} \exp \left(k\left(\alpha_{1}+\alpha_{2}-\alpha_{0}\right)\right)$

Pada hasil turunan fungsi likelihood dari Bivariate Generalized Poisson diperoleh persamaan yang masih mengandung parameter maka diselesaikan menggunakan iterasi Newton Rahpson dengan menggunakan persamaan:

$$
\hat{\boldsymbol{\theta}}_{(m+1)}=\hat{\boldsymbol{\theta}}_{(m)}-\mathbf{H}^{-1}\left(\hat{\boldsymbol{\theta}}_{(m)}\right) \mathbf{g}\left(\hat{\boldsymbol{\theta}}_{(m)}\right)
$$

Dimana,

$$
\begin{aligned}
& \boldsymbol{\theta}=\left(\mu_{0}, \boldsymbol{\beta}_{1}^{T}, \boldsymbol{\beta}_{2}^{T}, \alpha_{1}, \alpha_{2}, \alpha_{0}\right)^{T} \\
& \mathbf{g}^{T}\left(\hat{\boldsymbol{\theta}}_{(m)}\right)_{(k+1)}=\left(\frac{\partial \ln L(\boldsymbol{\theta})}{\partial \mu_{0}} \frac{\partial \ln L(\boldsymbol{\theta})}{\partial \boldsymbol{\beta}_{1}} \frac{\partial \ln L(\boldsymbol{\theta})}{\partial \boldsymbol{\beta}_{2}} \frac{\partial \ln L(\boldsymbol{\theta})}{\partial \alpha_{1}} \frac{\partial \ln L(\boldsymbol{\theta})}{\partial \alpha_{2}} \frac{\partial \ln L(\boldsymbol{\theta})}{\partial \alpha_{0}}\right)_{\boldsymbol{\theta}=\boldsymbol{\theta}_{(m)}}
\end{aligned}
$$

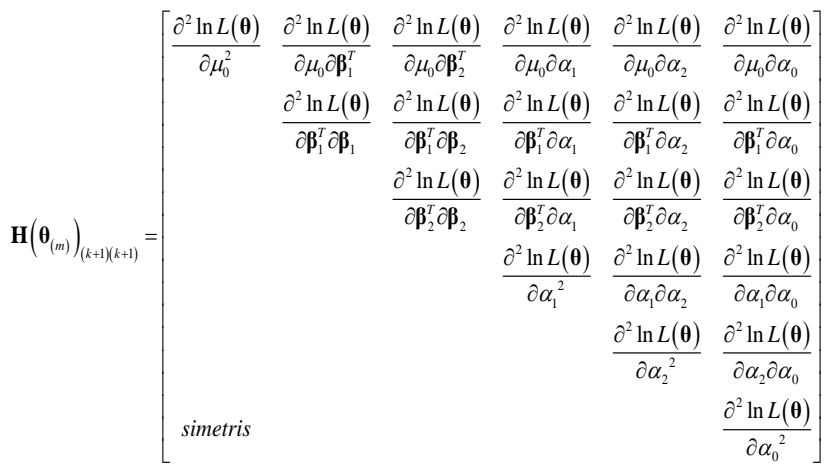

Matriks Hessian merupakan matriks yang berisi turunan kedua dari fungsi $\ln L(Q)$ terhadap parameter $\left(\mu_{0}, \boldsymbol{\beta}_{1}^{T}, \boldsymbol{\beta}_{2}^{T}, \alpha_{1}, \alpha_{2}, \alpha_{0}\right)^{T}$. Adapun langkah-langkah pen-dugaan parameter dengan iterasi Newton-Raphson adalah,

1. Menentukan nilai penduga awal parameter $L(\hat{\omega})$ dengan $\boldsymbol{\theta}=\left(\mu_{0}, \boldsymbol{\beta}_{1}^{T}, \boldsymbol{\beta}_{2}^{T}, \alpha_{1}, \alpha_{2}, \alpha_{0}\right)^{T}$, iterasi pada saat $\mathrm{m}=0$. Nilai penduga awal $\hat{\boldsymbol{\beta}}_{j(0)}$ diperoleh dengan metode OLS yaitu $\hat{\boldsymbol{\beta}}_{j(0)}=\left(\mathbf{X}^{T} \mathbf{X}\right)^{-1}\left(\mathbf{X}^{T} y_{j}\right) ; j=1,2$

2. Membentuk vektor gradien $\mathbf{g}(\boldsymbol{\theta})$.

3. Membentuk matriks Hessian dengan mensubstitusikan persamaan yang dihasilkan dari turunan kedua ke dalam persamaan (5).

4. Memasukkan nilai ke dalam $\hat{\boldsymbol{\theta}}_{(0)}$ elemen - elemen vektor $\mathbf{g}$ dan matriks $\mathbf{H}$ sehingga diperoleh vektor $\mathbf{g}\left(\hat{\boldsymbol{\theta}}_{(0)}\right)$ dan matriks $\mathbf{H}\left(\hat{\boldsymbol{\theta}}_{(0)}\right)$.

5. Mulai dari $m=0$ dilakukan iterasi pada persamaan $\hat{\boldsymbol{\theta}}_{j(m+1)}=\hat{\boldsymbol{\theta}}_{j(m)}-\mathbf{H}^{-1}\left(\hat{\boldsymbol{\theta}}_{(m)}\right) \mathbf{g}\left(\hat{\boldsymbol{\theta}}_{(m)}\right)$. Nilai $\quad \hat{\boldsymbol{\theta}}_{(0)}$ merupakan kumpulan penduga parameter yang konvergen saat iterasi ke-m.

6. Apabila belum mendapatkan penduga parameter yang konvergen, maka dilanjutkan ke langkah 5 hingga iterasi ke $\mathrm{m}=\mathrm{m}+1$. Iterasi akan berhenti jika nilai dari $\left\|\hat{\boldsymbol{\theta}}_{(m+1)}-\hat{\boldsymbol{\theta}}_{(m)}\right\| \leq \varepsilon$. 


\section{ii.) Pengujian Hipotesis Parameter Bivariate Generalized Poisson Regression}

Pengujian serentak parameter pada model Bivariate Generalized Poisson Regression dilakukan untuk mengetahui signifikansi parameter $\boldsymbol{\alpha}$ dan $\boldsymbol{\beta}$ secara bersama-sama dengan hipotesis sebagai berikut :

$\mathrm{H}_{0}: \alpha_{1}=\alpha_{2}=\beta_{j 1}=\beta_{j 2}=\ldots=\beta_{j \mathrm{k}}=0$

$\mathrm{H}_{1}$ : Ada salah satu $\alpha_{j}, \beta_{j \mathrm{k}} \neq 0 ; j=1,2$ dan $l=1,2, \ldots, \mathrm{k}$

Statistik uji dengan persamaan sebagai berikut.

$D(\hat{\boldsymbol{\beta}}) \sim-2 \ln \left(\frac{L(\hat{\omega})}{L(\hat{\Omega})}\right)=-2(\ln L(\hat{\Omega})-\ln L(\hat{\omega})) \sim \chi_{v}^{2}$

$D(\hat{\boldsymbol{\beta}})$ merupakan pendekatan dari distribusi $\chi^{2}$ dengan

derajat bebas $v$, dimana $v$ adalah jumlah parameter dibawah populasi dikurangi jumlah parameter dibawah $\mathrm{H}_{0}$. Kriteria Tolak $\mathrm{H}_{0}$ apabila $D(\hat{\boldsymbol{\beta}})>\chi_{(a, v)}^{2}$ maka terdapat variabel prediktor yang berpengaruh terhadap variabel respon dengan $\alpha$ adalah taraf signifikansi. Apabila hasil dari pengujian serentak adalah tolak $\mathrm{H}_{0}$, untuk itu perlu dilakukan pengujian terhadap parameter model Bivariate Generalized Poisson Regression secara parsial dengan menggunakan hipotesis sebagai berikut.

1. Parameter $\alpha$

$\mathrm{H}_{0}: \alpha_{j}=0$

$\mathrm{H}_{1}: \alpha_{j} \neq 0 ; j=1,2$

Statistik uji yang digunakan yaitu:

$$
Z_{\text {hit }}=\frac{\alpha_{j}}{S E\left(\alpha_{j}\right)}
$$

2. Parameter $\beta$

$\mathrm{H}_{0}: \beta_{j l}=0$

$\mathrm{H}_{1}: \beta_{j l} \neq 0 ; j=1,2$ dengan $l=1,2, \ldots, \mathrm{k}$

Statistik uji yang digunakan yaitu:

$$
Z_{h i t}=\frac{\hat{\beta}_{j l}}{S E\left(\hat{\beta}_{j l}\right)}
$$

Keputusan yang akan diambil untuk pengujian hipotesis parameter $\alpha$ dan $\beta$ adalah tolak $\mathrm{H}_{0}$ apabila nilai $\left|Z_{\text {hit }}\right|>Z_{\alpha / 2}$, dimana $\alpha$ adalah tingkat signifikansi yang digunakan.

\section{Multikolinieritas}

Pendeteksian multikolinieritas dapat dilakukan menggunakan nilai Variance Inflation Factor (VIF). Untuk regresi dengan lebih dari dua variabel definisi VIF adalah,

$$
V I F=\frac{1}{1-R_{j}^{2}} \quad ; j=1,2, \ldots, k
$$

dengan,

$R_{j}^{2}$ merupakan nilai koefisien determinasi antara variabel $x_{j}$ dengan variabel $x$ lainnya. Nilai $R_{j}^{2}$ berkisar antara 0 sampai dengan 1 sehinga nilai VIF akan seiring dengan kenaikan koefisien determinasi. Nilai VIF yang lebih dari 10 merupakan bukti cukup untuk mendeteksi adanya multikolinieritas [9].

\section{Pemilihan Model Terbaik}

Metode AIC adalah metode yang data digunakan untuk memilih model regresi terbaik yang ditemukan oleh Akaike.
Metode ini didasarkan pada metode Maximum Likelihood Estimation (MLE). Perhitungan nilai AIC menggunakan persamaan berikut,

$$
\text { AIC }=-2 \ln (\text { maximum likelihood })+2(\text { number of parameters })
$$

Model regresi terbaik adalah model regresi yang menghasilkan nilai AIC terkecil [10].

\section{E. Kematian Ibu dan Kematian Bayi}

Kematian ibu adalah kematian seorang perempuan yang terjadi selama kehamilan sampai dengan 42 hari setelah berakhirnya kehamilan, tanpa memperhatikan lama dan tempat terjadinya kehamilan, yang disebabkan atau dipicu oleh kehamilannya atau penanganan kehamilannya, tetapi bukan karena kecelakaan. Kematian bayi adalah kematian yang terjadi saat setelah bayi lahir sampai bayi belum berusia tepat 1 tahun. Penyebab kematian bayi ada dua macam yaitu endogen dan eksogen [11].

\section{METODOLOGI PENELITIAN}

\section{A. Sumber Data}

Data yang digunakan pada penelitian ini merupakan data sekunder yang diperoleh dari www.dinkes-jatengprov.go.id, dimana data yang digunakan yaitu Data Profil Kesehatan Provinsi Jawa Tengah tahun 2015. Unit pengamatan sebanyak 35 unit pengamatan terdiri atas 29 Kabupaten dan 6 Kota.

\section{B. Variabel Penelitian}

Variabel penelitian yang akan dianalisis dibagi menjadi dua yaitu variabel respon (Y) dan variabel prediktor $(\mathrm{X})$. Variabelvariabel yang digunakan disajikan pada Tabel 1.

Tabel 1.

Variabel Penelitian

\begin{tabular}{clc}
\hline \hline Variabel & \multicolumn{1}{c}{ Keterangan } & $\begin{array}{c}\text { Determinan } \\
\text { Konseptual }\end{array}$ \\
\hline Y1 & Jumlah kematian bayi & Proksi \\
Y2 & Jumlah kematian ibu & Proksi \\
X1 & Persentase persalinan oleh tenaga kesehatan & Antara \\
X2 & Persentase ibu hamil mendapatkan tablet Fe3 & Antara \\
X3 & Persentase komplikasi kebidanan yang & Antara \\
& ditangani & \\
X4 & Persentase rumah tangga ber-PHBS & Antara \\
X5 & Persentase ibu hamil melaksanakan program & Antara \\
& K4 & \\
\hline \hline
\end{tabular}

Tabel 2.

Struktur Data dalam Penelitian

\begin{tabular}{cccccccc}
\hline \hline Wilayah & $\mathrm{Y}_{1}$ & $\mathrm{Y}_{2}$ & $\mathrm{X}_{1}$ & $\mathrm{X}_{2}$ & $\mathrm{X}_{3}$ & $\mathrm{X}_{4}$ & $\mathrm{X}_{5}$ \\
\hline 1 & $\mathrm{Y}_{1.1}$ & $\mathrm{Y}_{2.1}$ & $\mathrm{X}_{1.1}$ & $\mathrm{X}_{2.1}$ & $\mathrm{X}_{3.1}$ & $\mathrm{X}_{4.1}$ & $\mathrm{X}_{5.1}$ \\
2 & $\mathrm{Y}_{1.2}$ & $\mathrm{Y}_{2.2}$ & $\mathrm{X}_{1.2}$ & $\mathrm{X}_{2.2}$ & $\mathrm{X}_{3.2}$ & $\mathrm{X}_{4.2}$ & $\mathrm{X}_{5.2}$ \\
3 & $\mathrm{Y}_{1.3}$ & $\mathrm{Y}_{2.3}$ & $\mathrm{X}_{1.3}$ & $\mathrm{X}_{2.3}$ & $\mathrm{X}_{3.3}$ & $\mathrm{X}_{4.3}$ & $\mathrm{X}_{5.3}$ \\
4 & $\mathrm{Y}_{1.4}$ & $\mathrm{Y}_{2.4}$ & $\mathrm{X}_{1.4}$ & $\mathrm{X}_{2.4}$ & $\mathrm{X}_{3.4}$ & $\mathrm{X}_{4.4}$ & $\mathrm{X}_{5.4}$ \\
$\ldots$ & $\ldots$ & $\ldots$ & $\ldots$ & $\ldots$ & $\ldots$ & $\ldots$ & $\ldots$ \\
35 & $\mathrm{Y}_{1.35}$ & $\mathrm{Y}_{2.35}$ & $\mathrm{X}_{1.35}$ & $\mathrm{X}_{2.35}$ & $\mathrm{X}_{3.35}$ & $\mathrm{X}_{4.35}$ & $\mathrm{X}_{5.35}$ \\
\hline \hline
\end{tabular}

Untuk memudahkan mengetahui pola data maka dibentuklah struktur data. Struktur data tersebut disusun berdasarkan variabel-variabel yang digunakan, baik variabel prediktor maupun variabel respon. Struktur data untuk penelitian ini ditunjukkan pada Tabel 2. 


\section{Langkah Analisis}

Pada penelitian ini ada beberapa langkah yang dilakukan, antara lain.

1. Jawa Tengah serta variabel-variabel yang diduga berpengaruh yaitu menggunakan peta tematik Provinsi Jawa Tengah yang dibagi menjadi 3 dengan menggunakan Natural Breaks.

2. Langkah-langkah untuk mengidentifikasi faktor-faktor yang berpengaruh terhadap jumlah kematian ibu dan jumlah kematian bayi dengan Bivariate Generalized Poisson Regression adalah,

1) Melakukan uji korelasi antar variabel respon yaitu jumlah kematian ibu dan jumlah kematian bayi.

2) Melakukan pemeriksaan kasus multikolinieritas dengan menggunakan kriteria VIF, untuk mengetahui apakah antar variabel prediktor yang diduga berpengaruh terdapat hubungan yang erat.

3) Melakukan pemodelan dengan menggunakan metode Bivariate Generalized Poisson Regression yang meliputi :

a. Mendapatkan penduga parameter model Bivariate Generalized Poisson Regression dengan menggunakan Maximum Likelihood Estimation (MLE).

i) Himpunan parameter dibawah populasi :

$$
(\Omega)=\left\{\mu_{0}, \boldsymbol{\beta}_{1}^{T}, \boldsymbol{\beta}_{2}^{T}, \alpha_{1}, \alpha_{2}, \alpha_{0}\right\}
$$

ii) Himpunan parameter dibawah $\mathrm{H}_{0}$ :

$$
(\omega)=\left\{\mu_{0}, \boldsymbol{\beta}_{1.0}, \boldsymbol{\beta}_{2.0}, \alpha_{1}, \alpha_{2}, \alpha_{0}\right\}
$$

b. Melakukan pengujian hipotesis untuk Bivariate Generalized Poisson Regression dengan menggunakan hipotesis sebagai berikut :

i) Parameter $\alpha$

$\mathrm{H}_{0}: \alpha_{1}=\alpha_{2}=0$

$\mathrm{H}_{1}$ : Ada salah satu $\alpha_{j} \neq 0 ; j=1,2$

ii) Parameter $\beta$

$\mathrm{H}_{0}: \beta_{j 1}=\beta_{j 2}=\ldots=\beta_{j \mathrm{k}}=0 ; j=1,2$

$\mathrm{H}_{1}$ : Paling sedikit ada satu $\beta_{j 1} \neq 0 ; j=1,2$ dengan $l=1,2, \ldots, \mathrm{k}$

4) Melakukan pengujian overdispersion atau underdispersion.

5) Menentukan model terbaik dari hasil all possible regression berdasarkan nilai AIC

\section{HASIL DAN PEMBAHASAN}

\section{A. Deskripsi Jumlah Kematian Ibu dan Jumlah Kematian Bayi Kabupaten/Kota di Jawa Tengah}

Pada tahun 2015 terdapat total 619 kematian ibu dan 5571 kematian bayi di Provinsi Jawa Tengah. Jumlah kematian ibu tertinggi yaitu sebanyak 52 jiwa tedapat di Kabupaten Brebes sedangkan terendah yaitu sebanyak 3 jiwa terdapat di Kota Magelang dan Kabupaten Temanggung. Jumlah kematian bayi tertinggi sebanyak 384 jiwa terjadi di Kabupaten Grobogan sedangkan terendah sebanyak 25 jiwa terjadi di Kota Magelang. Persebaran jumlah kematian ibu dan jumlah kematian bayi di Provinsi Jawa Tengah dapat dilihat sebagai berikut.

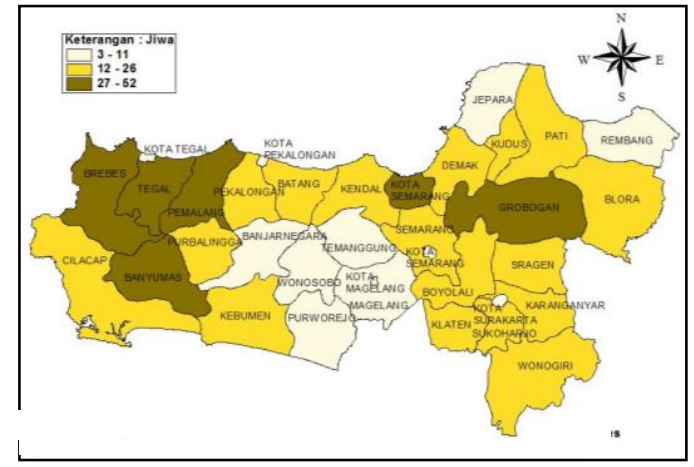

Gambar 1. Persebaran Jumlah Kematian Ibu di Jawa Tengah

Berdasarkan Gambar 1 dapat dilihat bahwa pada Kabupaten Banjarnegara, Temanggung, Wonosobo, Purworejo, Magelang, Jepara, Rembang, Kota Magelang, Tegal, Pekalongan, Surakarta serta Semarang memiliki jumlah kematian ibu pada interval 3-11, dimana jumlah ini masuk dalam kategori rendah. Jumlah kematian ibu paling rendah berada di Kota Magelang dan Kabupaten Temanggung dengan jumlah kematian sebanyak 3 jiwa. Pada kategori jumlah kematian sedang yaitu interval 12-26 terjadi di Kabupaten Cilacap, Kebumen, Purbalingga, Pekalongan, Batang, Kendal, Semarang, Demak, Kudus, Pati, Blora, Boyolali, Sragen, Karanganyar, Klaten, Sukoharjo dan Wonogiri. Kategori tinggi untuk jumlah kematian ibu yaitu pada interval 27-52 terdapat pada 6 Kabupaten/Kota di Provinsi Jawa Tengah yaitu di Kabupaten Banyumas, Brebes, Pemalang, Tegal, Grobogan dan Kota Semarang, dimana jumlah kematian tertinggi terdapat di Kabupaten Brebes dengan jumlah kematian 52 jiwa. AKI di Provinsi Jawa Tengah pada tahun 2015 tergolong sangat tinggi yaitu 111,6 per 100.000 kelahiran hidup. Angka ini lebih tinggi dari target tahun 2015 sebesar 102 per 100.000 kelahiran hidup. Oleh karena itu perlu peningkatan upaya penurunan kematian ibu.

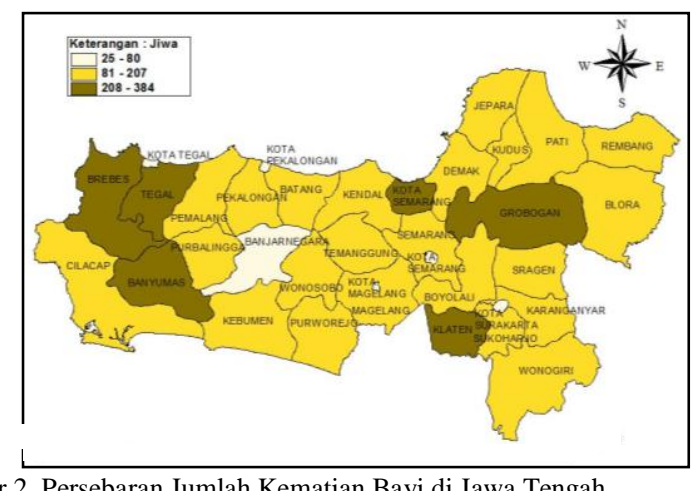

Gambar 2. Persebaran Jumlah Kematian Bayi di Jawa Tengah

Gambar 2 menunjukkan bahwa kategori jumlah kematian bayi yang termasuk rendah yaitu interval 25-80 terdapat di 6 Kabupaten/Kota di Jawa Tengah yaitu di Kota Tegal, Pekalongan, Salatiga, Magelang, Surakarta dan Kabupaten Banjarnegara, dimana jumlah kematian bayi terendah terdapat di Kota Magelang dengan jumlah kematian sebanyak 25 jiwa. Pada kategori sedang untuk jumlah kematian bayi yaitu pada interval 81-207 terdapat pada Kabupaten Pemalang, Purbalingga, Kebumen, Banjarnegara, Pekalongan, Wonosobo, Purworejo, Magelang, Batang, Kendal, Temanggung, 
Semarang, Boyolali, Cilacap, Sukoharjo, Karanganyar, Sragen, Demak, Kudus, Jepara, Pati, Rembang dan Blora. Pada 6 Kabupaten/Kota di Provinsi Jawa Tengah termasuk dalam kategori tinggi untuk jumlah kematian bayi yaitu pada interval 208-384 terdapat di Kabupaten Klaten, Banyumas, Brebes, Tegal, Grobogan dan Kota Semarang, dimana jumlah kematian bayi tertinggi terjadi sebanyak 384 jiwa yaitu di Kabupaten Grobogan.

\section{B. Pengujian Overdispersion atau Underdispersion}

Dikatakan overdispersion atau overdispersion apabila nilai variansnya lebih besar dari nilai rata-rata nya untuk setiap variabel respon. Berikut nilai mean dan varians dari jumlah kematian ibu dan jumlah kematian bayi.

Tabel 3.

Mean dan Varians Variabel Respon

\begin{tabular}{ccc}
\hline \hline Variabel & Mean & Varians \\
\hline Jumlah Kematian Ibu & 17,69 & 114,63 \\
Jumlah Kematian Bayi & 159,2 & 5595,3 \\
\hline \hline
\end{tabular}

Tabel 3 menunjukkan bahwa varians dari masing-masing variabel respon memiliki nilai lebih besar dari nilai rata-rata atau mean nya. Sehingga dapat diindikasikan bahwa terjadi kasus overdispersion atau overdispersion pada data jumlah kematian ibu serta jumlah kematian bayi. Pada penelitian ini, untuk memastikan terjadinya kasus overdispersion atau overdispersion dilakukan pengujian menggunakan uji Lagrange Multiplier. Hipotesis yang digunakan untuk uji Lagrange Multiplier pada penelitian ini adalah sebagai berikut. $H_{0}: \theta=0$ (Tidak terjadi overdispersion/underdispersion)

$H_{1}: \theta \neq 0$ (Terjadi overdispersion/underdispersion)

Pada variabel respon jumlah kematian ibu diperoleh hasil nilai $\mathrm{T}_{\mathrm{LM}}$ sebesar 11464,7. Nilai ini lebih besar dari $\mathrm{Z}_{(0,05 / 2)}=$ 1,96, sehingga dapat diketahui bahwa terdapat kasus overdispersion atau overdispersion dengan variabel respon jumlah kematian ibu. Selanjutnya pada variabel respon jumlah jumlah kematian bayi didapatkan nilai $\mathrm{T}_{\mathrm{LM}}$ sebesar 248,844 . Berdasarkan hasil tersebut dapat diketahui bahwa terdapat kasus overdispersion atau overdispersion dengan variabel respon jumlah kematian bayi. Diketahui bahwa kedua nilai $\mathrm{T}_{\mathrm{LM}}$ memiliki nilai lebih dari $Z_{(0,05)}=1,645$, maka dapat disimpulkan bahwa terjadi kasus overdispersion pada data jumlah kematian ibu dan jumlah kematian bayi.

\section{Pengujian Korelasi dan Multikolinieritas}

Kriteria yang harus dipenuhi sebelum melakukan analisis menggunakan Bivariate Generalized Poisson Regression adalah antar variabel respon harus memiliki keterkaitan yang erat namun antar variabel prediktor tidak boleh memiliki keterkaitan yang erat. Hubungan antar variabel respon dapat dilihat melalui nilai koefisien korelasi variabel jumlah kematian ibu dan jumlah kematian bayi. Berdasarkan hasil analisis didapatkan nilai koefisien korelasi untuk jumlah kematian ibu dan jumlah kematian bayi sebesar 0,7852, berarti terdapat hubungan yang erat antara jumlah kematian ibu dan jumlah kematian bayi di Provinsi Jawa Tengah pada tahun 2015. Selanjutnya berdasarkan hasil analisis didapatkan nilai VIF untuk setiap variabel prediktor kurang dari 10, sehingga dapat ditarik kesimpulan bahwa tidak terdeteksi adanya multikolinieritas antar variabel prediktor. Karena antar variabel respon terdapat hubungan yang erat dan antar variabel prediktor tidak terdapat hubungan yang erat, maka selanjutnya dapat dilanjutkan analisis menggunakan Bivariate Generalized Poisson Regression.

\section{Model Bivariate Generalized Poisson Regression}

Model Bivariate Generalized Poisson Regression merupakan suatu model yang sesuai diterapkan pada sepasang data count yang saling berkorelasi serta terjadi pelanggaran asumsi rata-rata sampel sama dengan ragam sampel pada distribusi Poisson dengan kata lain jika terjadi over/under dispersi. Sehingga selain $\mu$ dalam Genaralized Poisson terdapat juga $\alpha$ sebagai parameter dispersi. Pengujian parameter secara serentak dilakukan untuk mengetahui apakah terdapat minimal satu variabel yang berpengaruh terhadap model yang dihasilkan. Hipotesis yang digunakan untuk pengujian parameter secara serentak pada penelitian ini adalah sebagai berikut dengan hasil pengolahan data pada lampiran 6 . $\mathrm{H}_{0}: \alpha_{1}=\alpha_{2}=\beta_{j 1}=\beta_{j 2}=\ldots=\beta_{j 5}=0$

$\mathrm{H}_{1}$ : Paling sedikit ada satu $\alpha_{j}, \beta_{j l} \neq 0 ; j=1,2$ dan $l=1,2, \ldots, 5$

Berdasarkan hasil pemodelan data pada lampiran 1 diperoleh nilai devians sebesar 6669 dengan menggunakan tingkat signifikansi 5\% didapatkan $\chi_{(10 ; 0.05)}^{2}=18,307$. Karena nilai devians lebih besar dari $\chi_{(10 ; 0.05)}^{2}$ maka diperoleh keputusan tolak $\mathrm{H}_{0}$. Sehingga dapat disimpulkan bahwa paling sedikit ada satu variabel prediktor yang berpengaruh signifikan terhadap variabel respon.

Tabel 4

Estimasi Parameter Bivariate Generalized Poisson Regression.

\begin{tabular}{ccccc}
\hline \hline \multirow{2}{*}{ Parameter } & \multicolumn{2}{c}{ Jumlah Kematian Ibu $\left(\mu_{1}\right)$} & \multicolumn{2}{c}{ Jumlah Kematian Bayi $\left(\mu_{2}\right)$} \\
\cline { 2 - 5 } & Estimasi & SE & Estimasi & SE \\
\hline$\beta_{0}$ & 10,578353 & 0,460257 & 12,154957 & 0,176342 \\
$\beta_{1}$ & $-0,120823$ & 0,003986 & $-0,157507$ & 0,001661 \\
$\beta_{2}$ & 0,063520 & 0,003206 & 0,032192 & 0,001405 \\
$\beta_{3}$ & 0,004411 & 0,000319 & 0,012302 & 0,000111 \\
$\beta_{4}$ & $-0,008226$ & 0,000861 & $-0,054510$ & 0,000151 \\
$\beta_{5}$ & 0,018592 & 0,003866 & 0,115801 & 0,000902 \\
\hline \hline
\end{tabular}

Tabel 4 menunjukkan nilai estimasi parameter dari jumlah kematian ibu dan jumlah kematian bayi. Estimasi parameter $\alpha_{0}$, $\alpha_{1}$ dan $\alpha_{2}$ untuk jumlah kematian ibu dan jumlah kematian bayi berturut-turut yaitu 47,718, 1,071 dan 1,3708. Model yang didapatkan dari hasil penaksiran parameter Bivariate Generalized Poisson Regression untuk jumlah kematian ibu dan jumlah kematian ibu adalah sebagai berikut.

$\ln \left(\mu_{1}\right)=10,578353-0,120823 \mathrm{X}_{1}+0,06352 \mathrm{X}_{2}+0,004411 \mathrm{X}_{3}-0,008226 \mathrm{X}_{4}+0,018592 \mathrm{X}_{5}$

$\mu_{1}=\exp \left(10,578353-0,120823 \mathrm{X}_{1}+0,06352 \mathrm{X}_{2}+0,004411 \mathrm{X}_{3}-0,008226 \mathrm{X}_{4}+0,018592 \mathrm{X}_{5}\right)$

$\ln \left(\mu_{2}\right)=12,154957-0,157507 X_{1}+0,032192 X_{2}+0,012302 X_{3}-0,05451 X_{4}+0,115801 X_{5}$

$\mu_{2}=\exp \left(12,154957-0,157507 \mathrm{X}_{1}+0,032192 \mathrm{X}_{2}+0,012302 \mathrm{X}_{3}-0,05451 \mathrm{X}_{4}+0,115801 \mathrm{X}_{5}\right)$

Setelah model Bivariate Generalized Poisson Regression diperoleh, selanjutnya dilakukan pengujian parameter secara parsial untuk mengetahui variabel prediktor mana yang berpengaruh secara signifikan terhadap jumlah kematian ibu dan jumlah kematian bayi. Hipotesis yang digunakan untuk melakukan uji parsial pada penelitian ini adalah sebagai berikut. $\mathrm{H}_{0}: \alpha_{j}=0$ $\mathrm{H}_{1}: \alpha_{j} \neq 0 ; j=1,2$ 
Pengujian ini menggunakan statistik uji Z yang merupakan nilai estimasi dibagi dengan standar errornya. Kemudian dengan menggunakan taraf signifikansi $5 \%$ nilai $\mathrm{Z}$ dibandingkan dengan nilai $\mathrm{Z}_{(0.05 / 2)}=1,96$ dan tolak $\mathrm{H}_{0}$ apabila nilai dari $|\mathrm{Z}|>$ $\mathrm{Z}_{(\alpha / 2)}$. Berikut merupakan hasil pengujian parsial dari Bivariate Generalized Poisson Regression.

Tabel 5.

\begin{tabular}{cc}
\multicolumn{2}{c}{ Nilai $Z_{\text {hitung }}$ Parameter Dispersi } \\
\hline \hline Parameter & Nilai $Z_{\text {hitung }}$ \\
\hline$\alpha_{1}$ & 41,129 \\
$\alpha_{2}$ & 3,321 \\
\hline
\end{tabular}

Berdasarkan pada Tabel 5 menunjukkan bahwa untuk parameter alfa, masing-masing memiliki nilai $|\mathrm{Z}|$ lebih dari $\mathrm{Z}_{(0.05 / 2)}=1,96$. Maka dapat disimpulkan bahwa ketiga parameter alfa berpengaruh signifikan terhadap jumlah kematian ibu dan jumlah kematian bayi. Hipotesis yang digunakan untuk melakukan uji parsial untuk parameter kedua yaitu beta pada penelitian ini adalah sebagai berikut.

$\mathrm{H}_{0}: \beta_{j l}=0$;

$\mathrm{H}_{1}$ : Paling sedikit ada satu $\beta_{j l} \neq 0 ; j=1,2$ dan $l=1,2, \ldots, 5$

Pengujian ini menggunakan statistik uji yang sama yaitu $\mathrm{Z}$ yang merupakan nilai estimasi dibagi dengan standar errornya. Kemudian dengan menggunakan taraf signifikansi $5 \%$ nilai $\mathrm{Z}$ dibandingkan dengan nilai $\mathrm{Z}_{(0,05 / 2)}=1,96$ dan tolak $\mathrm{H}_{0}$ apabila nilai dari $|\mathrm{Z}|>\mathrm{Z}_{(\alpha / 2)}$. Berikut merupakan hasil pengujian parsial dari Bivariate Generalized Poisson Regression.

Tabel 6.

Nilai $Z_{\text {hitung }}$ Model Bivariate Generalized Poisson Regression

\begin{tabular}{ccc}
\hline \hline Parameter & Jumlah Kematian Ibu $\left(\mu_{1}\right)$ & Jumlah Kematian Bayi $\left(\mu_{2}\right)$ \\
\hline$\beta_{0}$ & 68,928 & 22,984 \\
$\beta_{1}$ & $-94,822$ & $-30,309$ \\
$\beta_{2}$ & 22,9120 & 19,810 \\
$\beta_{3}$ & 111,300 & 13,811 \\
$\beta_{4}$ & $-362,272$ & $-9,559$ \\
$\beta_{5}$ & 128,447 & 4,809 \\
\hline \hline
\end{tabular}

Tabel 6 menunjukkan bahwa untuk model jumlah kematian ibu semua variabel prediktornya memiliki nilai $|\mathrm{Z}|$ yang lebih besar dari 1,96 sehingga dapat dijelaskan bahwa variabel persentase persalinan oleh tenaga kesehatan, persentase ibu hamil mendapatkan tablet Fe3, persentase komplikasi kebidanan yang ditangani, persentase rumah tangga ber-PHBS dan persentase ibu hamil melaksanakan program K4 berpengaruh secara signifikan terhadap jumlah kematian ibu. Untuk model jumlah kematian bayi memiliki hasil yang sama yaitu untuk semua variabel prediktor yaitu persentase persalinan oleh tenaga kesehatan, persentase ibu hamil mendapatkan tablet $\mathrm{Fe} 3$, persentase komplikasi kebidanan yang ditangani, persentase rumah tangga ber-PHBS dan persentase ibu hamil melaksanakan program $\mathrm{K} 4$ memiliki nilai $|\mathrm{Z}|$ yang lebih besar dari 1,96 sehingga dapat dijelaskan bahwa variabel prediktor tersebut juga berpengaruh secara signifikan terhadap jumlah kematian bayi.

\section{E. Pemilihan Model Bivariate Generalized Poisson Regression Terbaik}

Untuk mendapatkan model terbaik yang dapat diterakan pada kasus jumlah kematian ibu dan jumlah kematian bayi di Provinsi Jawa Tengah dilakukan dengan melakukan pembandingan nilai AIC dari seluruh model yang mungkin terjadi pada model Bivariate Generalized Poisson Regression dimana model dengan nilai AIC terkecil merupakan model yang terbaik. Berikut merupakan nilai AIC dari masing-masing kemungkinan model Bivariate Generalized Poisson Regression.

Tabel 7.

Kriteria Kebaikan Model

\begin{tabular}{|c|c|}
\hline Variabel Prediktor Model & Nilai AIC \\
\hline $\mathrm{X}_{3}$ & 158357 \\
\hline $\mathrm{X}_{1} \mathrm{X}_{3}$ & 34742 \\
\hline $\mathrm{X}_{1}, \mathrm{X}_{3}, \mathrm{X}_{4}$ & 3910 \\
\hline $\mathrm{X}_{1}, \mathrm{X}_{3}, \mathrm{X}_{4}, \mathrm{X}_{5}$ & 239771 \\
\hline $\mathrm{X}_{1,} \mathrm{X}_{2}, \mathrm{X}_{3}, \mathrm{X}_{4}, \mathrm{X}_{5}$ & 13359 \\
\hline
\end{tabular}

Tabel 7 menunjukkan nilai AIC dari masing-masing model yang mungkin untuk Bivariate Generalized Poisson Regression berdasarkan pemilihan variabel prediktor yang digunakan. Berdasarkan pada hasil tersebut dapat dilihat bahwa nilai AIC terkecil diperoleh dari model Bivariate Generalized Poisson Regression dengan tiga variabel prediktor yaitu sebesar 3910 dimana ketiga variabel prediktor tersebut diantaranya persentase persalinan oleh tenaga kesehatan, persentase komplikasi kebidanan yang ditangani serta persentase rumah tangga ber-PHBS.

\section{KESIMPULAN DAN SARAN}

\section{A. Kesimpulan}

Berdasarkan hasil analisis yang telah dijelaskan pada BAB IV, didapatkan beberapa kesimpulan sebagai berikut.

1. Terdapat 619 kasus kematian ibu dan 5571 kasus kematian bayi yang terjadi di Provinsi Jawa Tengah. Jumlah kematian ibu tertinggi yaitu sebanyak 52 jiwa tedapat di Kabupaten Brebes. Jumlah kematian bayi tertinggi sebanyak 384 jiwa terjadi di Kabupaten Grobogan. Nilai ini masih cukup tinggi dan perlu menjadi perhatian khusus bagi pemerintah.

2. Model yang diperoleh dengan menggunakan Bivariate Generalized Poisson Regression menghasilkan nilai AIC sebesar 13359. Model yang dihasilkan adalah sebagai berikut.

$\ln \left(\mu_{1}\right)=10,578353-0,120823 X_{1}+0,06352 X_{2}+0,004411 X_{3}-0,008226 X_{4}+0,018592 X_{5}$ $\ln \left(\mu_{2}\right)=12,154957-0,157507 X_{1}+0,032192 X_{2}+0,012302 X_{3}-0,05451 X_{4}+0,115801 X_{5}$

Berdasarkan hasil pengujian parameter model Bivariate Generalized Poisson Regression menunjukkan bahwa untuk model jumlah kematian ibu dan jumlah kematian bayi variabel persentase persalinan oleh tenaga kesehatan, persentase ibu hamil mendapatkan tablet Fe3, persentase komplikasi kebidanan yang ditangani, persentase rumah tangga ber-PHBS dan persentase ibu hamil melaksanakan program K4 berpengaruh secara signifikan terhadap jumlah kematian ibu di Provinsi Jawa Tengah. Model terbaik yang diperoleh merupakan model Bivariate Generalized Poisson 
Regression dengan menggunakan tiga variabel prediktor yaitu persentase persalinan oleh tenaga kesehatan, persentase komplikasi kebidanan yang ditangani serta persentase rumah tangga ber-PHBS. Nilai AIC yang dihasilkan dengan menggunakan tiga variabel tersebut adalah sebesar 3910, jauh lebih baik apabila dibandingkan dengan model Bivariate Generalized Poisson Regression dengan menggunakan seluruh variabel. Model yang dihasilkan adalah sebagai berikut.

$\ln \left(\mu_{1}\right)=12,1-0,076030 \mathrm{X}_{1}-0,000364 \mathrm{X}_{3}-0,020090 \mathrm{X}_{4}$

$\ln \left(\mu_{2}\right)=10,99-0,040300 X_{1}+0,011340 X_{3}-0,005421 X_{4}$

Variabel yang berpengaruh secara signifikan untuk model jumlah kematian ibu yaitu variabel persentase persalinan oleh tenaga kesehatan dan persentase rumah tangga berPHBS. Untuk model jumlah kematian bayi semua variabel prediktor yaitu persentase persalinan oleh tenaga kesehatan, persentase komplikasi kebidanan yang ditangani dan persentase rumah tangga ber-PHBS berpengaruh secara signifikan terhadap jumlah kematian bayi.

\section{B. Saran}

Berdasarkan penelitian yang telah dilakukan, saran yang dapat diberikan kepada pihak Dinas Kesehatan Provinsi Jawa Tengah yaitu Dinas Kesehatan Provinsi Jawa Tengah dapat bekerja sama dengan puskesmas, bidan maupun rumah sakit di wilayah tersebut untuk menghimbau masyarakat agar melaksanakan program K4 dimana dalam program tersebut telah dilengkapi dengan berbagai medical check up yang sangat penting untuk memantau kesehatan ibu dan janin didalam kandungannya.

\section{DAFTAR PUSTAKA}

[1] Sofro A., (2009). Generalized Poisson Regression pada Pemodelan Data Klaim Resiko Sendiri : PT. Asuransi Tripakarta Surabaya. Tesis. ITS (Institut Teknologi Sepuluh Nopember Surabaya).

[2] Listiani, Y. (2010). Pemodelan Regresi Generalized Poisson pada Faktor-Faktor yang Mempengaruhi Angka Kematian Bayi di Jawa Timur Tahun 2007. Penelitian. Institut Teknologi Sepuluh Nopember Surabaya.

[3] Arkandi, I. (2015). Analisis Faktor Risiko Kematian Ibu dan Kematian Bayi dengan Pendekatan Regresi Poisson Bivariat di Provinsi Jawa Timur Tahun 2013. Penelitian. Institut Teknologi Sepuluh Nopember Surabaya.

[4] Ismail, N. \& Jemain, A. A. (2005). Generalized Poisson Regression : An Alternative for Risk Classification. Jurnal Teknologi University Teknologi Malaysia, Vol 43 Page 39-54. http://www.penerbit.utm.my/onlinejournal/. Tanggal Akses :14 Agustus 2016.

[5] Zamani, H., Faroughi P., \& Ismail N. (2013). Bivariate Generalized Poisson Regression Model : Applications on Health Care Data. SpingerVerlag Berlin Heidelberg.

[6] Famoye, F., Wulu, J.T. \& Singh, K.P. (2004). On The Generalized Poisson Regression Model With an Application to Accident Data. Journal of Data Science 2, Hal. 287-295. http://www.sinica.edu/. Tanggal Akses: 14 Agustus 2016.

[7] Cameron, A.C \& Trivedi, P.K. (1998). Regression Analysis of Count Data. Cambrige University Press. USA.

[8] Karlis, D \& Ntzoufras, I. (2005). Bivariate Poisson Regression Models in R. Journal of Statistical Software, Vol 14 1-36.

[9] Li, F. (2000). Multicoliniearity. Departemen of Statistics, Stockholm University, Hal. 1-10. http://people.su.se/. Tanggal Akses : 14 Agustus 2016.

[10] Akaike, H. (1978). A Bayesian Analysis of The Minimum AIC Procedure. Annals of the Institute of Atatistical Mathematics, Part A Hal. 194 . Diakses pada : http://www.ism.ac.jp/editsec/aism-/pdf/ Tanggal Akses : 14 Agustus 2016.
[11] Dinas Kesehatan. (2015). Profil Kesehatan Provinsi Jawa Tengah Tahun 2015. Semarang : Dinas Kesehatan Provinsi Jawa Tengah. www.dinkesjatengprov.go.id. Tanggal Akses : 14 Agustus 2016. 